\title{
Analisis Video Conference Polycom VSX 7000 \\ Dengan Standarisasi ITU (International Telecmmunication Union) yang Tergabung Dalam INHERENT
}

\author{
Happy Reksa \\ Umitra Lampung
}

\begin{abstract}
Abstrak
Video Conference adalah perangkat komunikasi interaktif yang memungkinkan kedua pihak atau lebih dilokasi berbeda dapat dapat berinteraksi melalui pengiriman dua arah audio dan visio. Untuk dapat dialakuanya Video Conference harus sesuai dengan Standarisasi ITU (International Telecmmunication Union) agar komuikasi tersebut sesuai dengan keinginan. Video Conference telah banyak digunakan dalam kehidupan. Misalnya untk bisnis, pendidikan, militer dan keperluan lain sebagainya. Dalam bidang pendidikan, Video Conference dapat dilakukan untk keperluan pendidikan jarak jauh. Selain dapat dilakukan untuk pendidikan jarak jauh, Video Conference dapat digunakan untuk rapat dengan Universias- Universitas di kota lain. Maka dari itu Universitas Bandar Lampung tergabung dengan INHERENT (Indonesia Higher Education Network) untuk mengikuti acara video coneference . jaringan INHERENT ini adalah jaringan komunikasi tertutup antar perguruan tinggi di Indonesia. Untuk dapat melakukan konerensi INHERENT , dapat mengakses Ke dalam MCU (Multipoint Control Unit) dengan DIKTI sebagai network center. Kegiatan INHERENT menggunakan Video Conference Polycom VSX 7000, sebuah fasilitas yang diperoleh dari hibah INHERENT tahun 2007 oleh DIKTI. Penelitian ini dilakukan untuk mengukur kesesuaian Video Conference Polycom VSX 7000 dengan standarisasi ITU (International Telecmmunication Union).
\end{abstract}

Keyword : Video Conference . International Telecmmunication Union. Multipoint Control Unit

\section{INTRODUCTION}

Video Conference merupakan seperangkat alat teknologi telekomunikasi interaktif yang memungkinkan kedua pihak atau lebih di lokasi berbeda dapat berinteraksi pengiriman dua arah audio dan video secara bersamaan. Tehnologi yang digunakan dalam conferensi video ini adalah system komperesi digital audio dan vide stream secara nyata.

Streaming adalah sebuah teknologi untuk memainkan file video atau audio secara langsung ataupun dengan pre-recorder dari sebuah mesin server (web server) . Dengan kata lain, file video ataupun audio yang terletak dalam sebuah server dapat secara langsung pada browser saat proses buffering mulai berjalan. File video atau audio di stream, akan berbentuk sebuah buffer di komputer client, dan data video - audio tersebut akan mulai di download ke dalam buffer yang telah terbentuk pada mesin client. Dalam waktu sepersekian detik, buffer telah terisi penuh dan secara otomatis file video audio langsung dijalankan oleh sistem. Sistem akan membaca informasi dari buffer dan tetap melakukan proses download file, sehingga proses streaming tetap berlangsung ke computer client. Hardware atau software yang melakukan kompresi disebut codec. Angka codec mencapai hingga 1:500 digital yang dihasilkan 1s dan 0s dibagi menjadi paket label, yang kemudian dikirimkan melalui jaringan digital . penggunaan model audio dalam saluran pengiriman memungkinkan penggunaan Plain Old Telphone System atau POTS, dalam beberapa aplikasi kecepatan rendah seperti video telephon, karena POTS merubah semua getaran digital dari gelombang analog dalam rentang spectrum audio.

Polycom VSX 7000. Perangkat Polycom VSX 7000 merupkan perangkat Video Conference yang digunakan pada Universitas Bandar Lampung yang terhubug dalam INHERENT (Indonesia Higher Education Network) dengan dikti sebagai network center. Yang menghubungkan antar perguruan tiggi di Indonesia. Perangkat ini memiliki IP 202.162.205.76

Design jaringan aplikasi video Didalam jaringan aplikasi video sau 
dara harus lebih jeli melihat hal - hal yang menjadi kunci faktor dari keberhasilan jaringan aplikasi video itu sendiri.

Faktor - faktornya

antara lain:

1. Codec Coding/Decoding yang mana merupakan otak dari system. Dankeberhasilan dari komunikasi visual sangatlah tergantung dari perangkat ini.

2. BandwidthSebuah kapasitas transmisi medium menuju pada transmit info (video, audio \& data). Bila digambarkan aliran telpon itu sebagai pipa air, bandwidth adalah ukuran dari pipa itu sendiri sedangkan isi yang mengalir didalam nyaadalah informasi. Isinya dalam bentuk Kbps (Kilo bits persecond). Untuk Video Conferencedi rekomendasikan 384 Kbps untuk bisa dihasilkan kualitas yang lebih baik. Namun saat ini telah banyak perangkat Video Conference yang dapat berkomunikasi dengan hanya menghasilkan kurang dari 128 Kbps bahkan sampai pada bandwidth 64 Kbps.

3. Resolution Persepsi resolusi dimana hubungan antararesolusi adalah pada ukurannya. Biasanya penggambaran pada penulisannyaadalah dot atau pixel. Berikutini standarisasi resolusi video.

4. Framerate Perkiraan framerate 22 fps pada penglihatanmata manusia sebagai pergerakangambar yang halus.Ukuran framerate untuk Amerika dan sekitarnya adalah 30fps dengan bentuk standarisasi video NTSC yangukuran gambarnya adalah $704 \mathrm{x}$ 480(pixel x line), sedangkan eropa dan Indonesia adalah25 fps dengan bentuk standarisasi video PAL yang ukuran gambarnya 704 x 576

Perangkat Lunak Endpoint Selain perangkat keras endpoint saat ini telah ada perangkat lunak endpoint bagi yang tidak memiliki perangkat kerasnya. Sistem kerjanya sama, hanya yang perlu dipersiapkan adalah mikropon dan kamera untuk dapat berkomunikasi.

Aplikasi ini prinsip kerjanya samaseperti bila menggunakan perangkat keras endpoint semua intruksi penggunaannya ada di dalam aplikasi tersebut. Yang saudara butuhkan hanyalah kamera yang biasa saudara gunakan dan mikropon.Dan yang paling penting diperhatikan adalahPC atau laptop yang dapat mendukung aplikasi ini.

Perangkat Keras Endpint. Perangkat yang digunakan untuk melakukan Video Conference. Dalam setiap Video Conference dibutuhkan perangkat keras endpoint agar dapat melakukan komunikasi visual baik itu point to point maupun multipoint.

MCU (Multipoint Control Unit) MCU ini di gunakan ketika akanmelakukan Video Conference dengan lebih dari 2 peserta yang mana membutuhkan komunikasi multipoint. MCU ini dapat memudahkan kita sebagai admin dalam mengatur komunikasi yang melibatkan banyak user/peserta. Sedangkan untuk user/pesertayang ingin melihat konferensi dapat juga mengaksesnya ke dalam MCU dan tampilannya berbentuk streaming. Saat ini di Pustekkom mempunyai 2 perangkat MCU yaitu
Codian 4210 dengan kapasitas 20 userdan Codian 4215 dengan kapasitas 30 user.

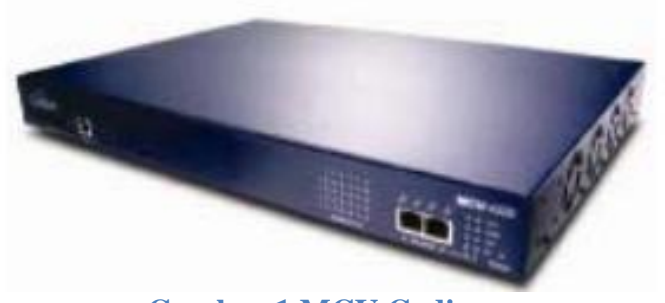

Gambar 1 MCU Codian

Ketika ingin melakukan Video Conference dengan lebih dari 2 peserta /endpoint atau multipoint maka diperlukan MCU untuk dapat mengendalikan dan mengatur Video Conference yang sedang berlangsung. MCU dapat mendukung Video Conferencemultipoint yang tidak hanya dengan perangkat keras akan tetapi juga dapat mendukung perangkat lunak endpoint

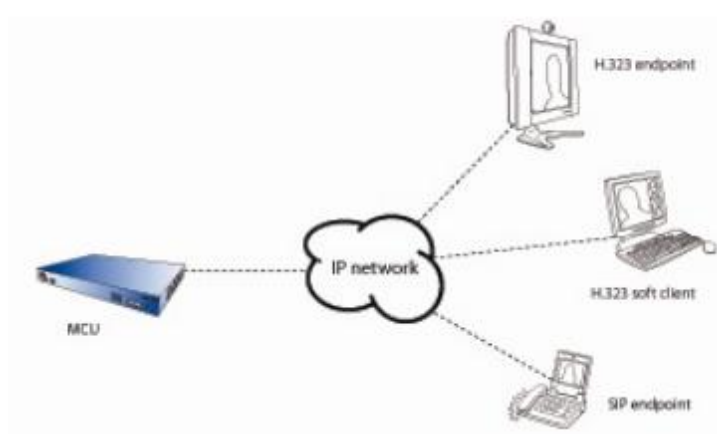

Gambar 2 Skema Hubungan MCU Dengan Endpoind

\section{Standarisasi ITU ( International Telecommunication Union )}

Merupakan bentuk standarisasi telekomunikasi internasional. Semua perangkat Video Conference harus memenuhi standarisasi ITU,ini di karenakan rekomendasi darisemua industri telekomunikasi.Didalam Video Conference menggunakan 2 standarisasi ITU, yaitu:

1. H.320(Standard ISDN)

Merupakan jendela standarisasi Video Conferencepada circuit jaringan yang dipilih

2. H.323 (Standard IP)

Merupakan jendela standarisasi Video Conference pada paket jaringan yang dipilih

\section{INHERENT (Indonesia Higher Education Network)}

Direktorat Jenderal Pendidikan Tinggi pada tahun 2006 telah membangun suatu jaringan komputer antar perguruan tinggi yang dinamakan INHERENT. Adapun tujuan dan fungsi utama jaringan ini adalah untuk meningkatkan mutu pendidikan tinggi di Indonesia melalui pemanfaatan teknologi informasi dan komunikasi (TIK) untuk menunjang kegiatan tridarma serta pengelolaan perguruan tinggi. Pemanfaatan TIK dalam pendidikan tinggi juga 
diharapkan dapat memacu penggunaansumber daya secara bersama baik berupa sumber daya informasi maupun sumber daya komputasi dan yang tak kalah pentingnya adalah sumber daya manusia. Sumber daya informasi seperti perpustakaan digital, pangkalan data, atau repository informasi diharapkan dapat dimanfaatkan secara bersama dengan memanfaatkan keterhubungan maya yang difasilitasi oleh INHERENT, dengan tentu saja tetap memerhatikan aturan universal seperti hak cipta atau hak atas kekayaan intelektual lainnya. Sementara itu, setiap unit komputer atau piranti elektronik lainnya yang terhubung pada jaringan INHERENT merupakan sumber daya komputasi yang dapat dimanfaatkan secara bersama misalnya dalam keperluan penelitian atau bpraktikum. Fasilitas jaringan INHERENT diharapkan juga dimanfaatkan untuk keperluan pembelajaran jarak jauh (distance learning), khususnya berbasis TIK (e-learning) dengan memanfaatkan fasilitas video-conference atau video-streaming. Untuk itu, perguruan tinggi perlu mengembangkan sistem dan tata aturan agar pembelajaran semacam ini dapat diintegrasikan sebagai bagian integral dari kurikulum akademik dan pembelajaran mahasiswa.

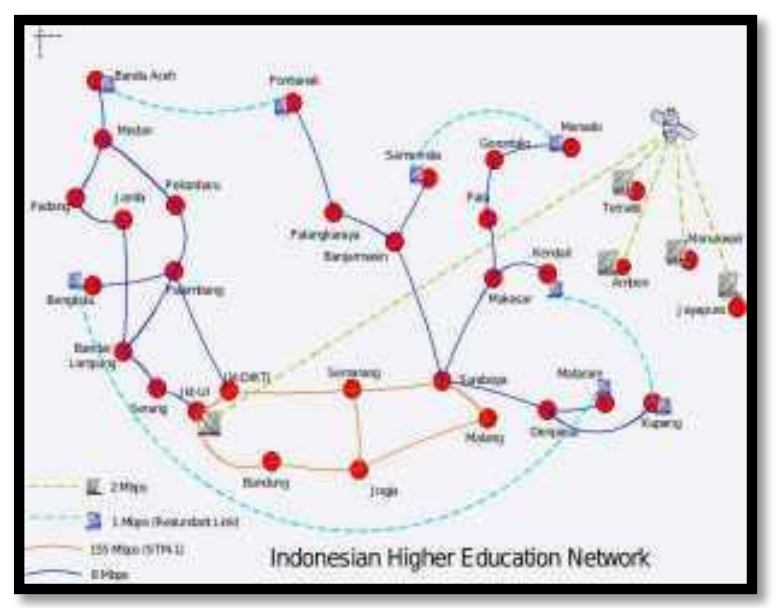

Gambar 3 peta jaringan INHERENT DIKTI di Indonesia

\section{PROCEDURE}

Dalam melakukan pengamatan, penulis melakukan 2 statement yang ada untuk memulai proses dilakukanya Video Conference pada Universitas Bandar Lampung. Pertama, awal mula Universitas Bandar Lampung tergabung dalam INHERENT . selanjutnya akan dijelaskan secara detil bagaimana proses Video Conference tergabung pada MCU DIKTI sebagai server untuk kemudian berlangsung Confring. Adapun penjabaranya adalah: a. Untuk dapat bergabung ke INHERENT, dapat dilakukan dengan menghubungkan perguruan tinggi asal (kota/propinsi) ke simpul lokal terdekat. Yang dimaksud dengan simpul lokal terdekat adalah yang terdekat secara geografis.

b. Setelah itu Simpul lokal wajib mempertimbangkan kondisi penggunaan wireless di lokasi masing masing agar tidak mengganggu alat komunikasi milik entitas lain diluar INHERENT.

c. Setelah terhubungkan secara fisik dengan jaringan INHERENT, maka perlu dibuat penyesuaian untuk interkoneksi antara jaringan perguruan tinggi yang akan menyambung ke INHERENT dengan jaringan di dalam INHEREN

d. INHERENT akan memfasilitasi perangkat Video Conference Polycom VSX 7000 serta melakukan instalasi, kemudian pengalokasian IP address dan membuat kebijakan routing (routing policy). Alokasi masing-masing perguruan tinggi yang akan terhubung ke INHERENT sangat bergantung dengan kondisi jaringan setempat.

e. . Dengan tergabungnya perguruan tinggi ke INHERENT, maka transaksi transaksi elektronik seperti e-mail, web, dan aplikasi lainnya yang berbasis IP (IP based application) dapat dan harus dilakukan melalui INHERENT (tidak melalui Internet).

UML (Unified Modeling Language)

\section{a. Use Case}




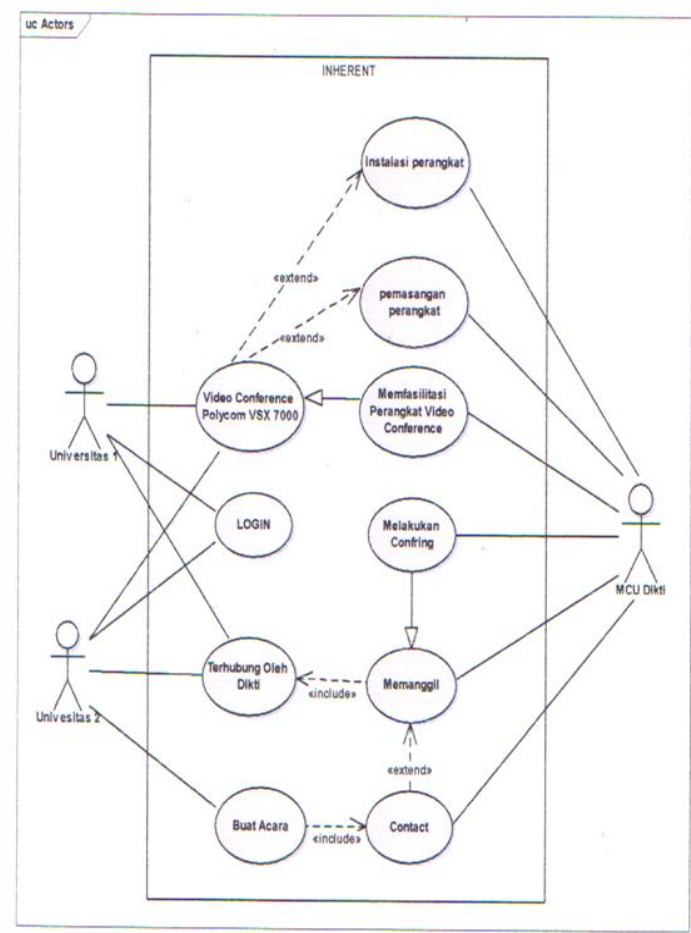

Gambar 4 Usecase Sistem Video Conference

\section{b. Class Diagram}

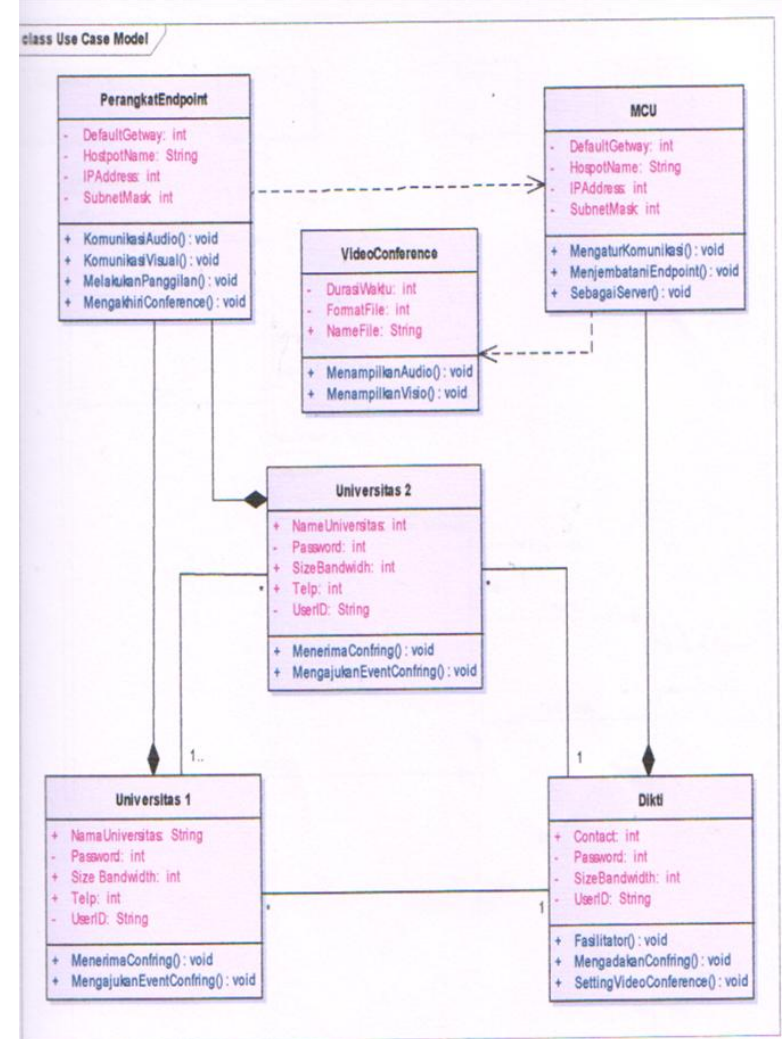

Gambar 5 Class Diagram Sistem Video Conference c. Activity Diagram

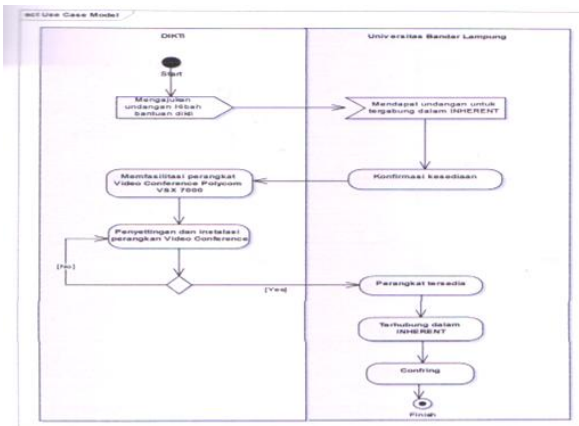

Gambar 6 Activity Diagram

\section{RESULT}

Kesesuaian Standarisasi ITU (International Telecomunicatin Union) melakukan kesesuaian standarisasi konferensi video melalui internet, kita perlu menghitung kebutuhan bandwidth untuk kesuksesanya sebuah konferensi video. Secara umum ada dua kebutuhan bandwidth yang harus dipenuhi, yaitu:

- Kebutuhan bandwidth untuk mengirimkan sinya gambar/video

- Kebutuhan bandwidth untuk mengoromkan sinyal suara/audio. 


\begin{tabular}{|c|c|c|c|}
\hline H.323 & $\begin{array}{l}\text { 1996/1998 Non-Graduated Bandwidth } \\
\text { Packet Switched network (Ethernet) }\end{array}$ & Format & Polycom VSX 7000 \\
\hline \multirow[t]{4}{*}{ Video } & \multirow[t]{2}{*}{ H.261 } & $\begin{array}{l}\text { CIF ( } 352 \text { Pixels per Line by } \\
288 \text { lines) }\end{array}$ & $\checkmark$ \\
\hline & & $\begin{array}{l}\text { QCIF (176 Pixels per Line by } \\
144 \text { lines) }\end{array}$ & \\
\hline & \multirow[t]{2}{*}{ H.263 } & $\begin{array}{l}\text { iSIF (128Pixels per Line by } 96 \\
\text { lines) }\end{array}$ & \\
\hline & & $\begin{array}{l}\text { 4SIF (704 Pixels per Line by } \\
576 \text { lines) }\end{array}$ & \\
\hline \multirow[t]{3}{*}{ Audio } & G.711 & $\begin{array}{l}\text { Frekwensi } 3 \mathrm{KHz} \text { dan } \\
\text { Bandwidth } 56 \mathrm{Kbps}\end{array}$ & $\checkmark$ \\
\hline & G.722 & $\begin{array}{l}\text { Frekwensi } 7 \mathrm{KHz} \text { dan } \\
\text { Bandwidth } 56 \mathrm{Kbps}\end{array}$ & \\
\hline & G.728 & $\begin{array}{l}\text { Frekwensi } 3 \mathrm{KHz} \text { dan } \\
\text { Bandwidth } 16 \mathrm{Kbps}\end{array}$ & \\
\hline \multirow[t]{2}{*}{$\begin{array}{l}\text { Multiplexing } \\
\text { Control }\end{array}$} & H.225 & $\begin{array}{l}\text { Frame synchronous control and } \\
\text { indication signals for audio } \\
\text { visual systems }\end{array}$ & $\checkmark$ \\
\hline & H.242 & $\begin{array}{l}\text { Between visual telephone } \\
\text { systems and terminal } \\
\text { equipment on non graduated } \\
\text { bandwidth }\end{array}$ & \\
\hline \multirow[t]{8}{*}{ Network } & \multirow[t]{5}{*}{ H.323 } & QOS & \\
\hline & & RSVP Standards & \\
\hline & & $\begin{array}{l}\text { Packet Loss based Down } \\
\text { Speeding }\end{array}$ & \\
\hline & & TCP/IP; & $\checkmark$ \\
\hline & & DHCP; & \\
\hline & & Auto Gatekeeper discovery & \\
\hline & & $\begin{array}{l}\text { Dual tone Multi Frequency } \\
\text { Signaling }\end{array}$ & \\
\hline & & QoS; & \\
\hline
\end{tabular}

Tabel 1 Implementasi Standarisasi

Standarisasi Video yang digunakan dalam Video Conference Polycom VSX 7000 yang digunakan dalam format videonya adalah CIF (352 Pixels per Line by 288 lines). Format standarisasi untuk frekuensi audio yang digakan adalah Frekwensi $3 \mathrm{KHz}$ dan Bandwidth 56 Kbps. Sinyal audio visual. Menggunakan network TCP/IP.

Kuisioner. Setelah dilakukanya pengumpulan data dari kuisioner mahasiswa, maka data yag diperoleh kemudian dikelola dengan menggunakan metode Rating Scale. Rating Scale adalah adalah alat pengumpul data yang digunakan dalam observasi untuk menjelaskan, menggolongkan, menilai individu atau situasi Rating Scale adalah alat pengumpul data yang berupa suatu daftar yang berisi ciri-ciri tingkah laku/sifat yang harus dicatat secara bertingkat. Rating Scale merupakan sebuah daftar yang menyajikan sejumlah sifat atau sikap sebagai butirbutir atau item. Dari beberapa pendapat tersebut, dapat disimpulkan pengertian Rating Scale adalah salah satu alat untuk memperoleh data yang berupa suatu daftar yang berisi tentang sfat/ciri-ciri tingkah laku yang ingin diselidiki yang harus dicatat secara bertingkat.Penilaian yang diberikan oleh observer berdasarkan observasi spontan terhadap perilaku orang lain, yang berlangsung dalam bergaul dan berkomunikasi sosial dengan orang itu selama periode waktu tertentu. Unsur penilaian terdapat dalam pernyataan pandangan pribadi dari orang yang menilai subyek tertentu pada masing-masing sifat atau sikap yang tercantum dalam daftar. Penilaian itu dituangkan dalam bentuk penentuan gradasi antara sedikit sekali dan banyak sekali atau antara tidak ada dan sangat ada.

Karena penilaian yang diberikan merupakan pendapat pribadi dari pengamat dan bersifat subyektif, skala penilaian yang diisi oleh satu pengamat saja tidak berarti untuk mendapatkan gambaran yang agak obyektif tentang orang yang dinilai. Untuk itu dibutuhkan beberapa skala penilaian yang diisi oleh beberapa orang, yang 
kemudian dipelajari bersama-sama untuk mendapatkan suatu diskripsi tentang kepribadian seseorang yang cukup terandalkan dan sesuai dengan kenyataan.

Penyusunan instrument rating scale harus bias mengartikan setiap angka yang diberikan secara alternative jawaban pada setiap item .

Berdasarkan jawaban interval yang telah disediakan , maka bobot nilai yang telah ditentuka adalah:

\begin{tabular}{|l|l|l|}
\hline Boot Nilai & Kode & Keterangan \\
\hline 1 & SK & Sangat kurang \\
\hline 2 & K & Kurang \\
\hline 3 & C & Cukup \\
\hline 4 & B & Baik \\
\hline 5 & SB & Sangat baik \\
\hline
\end{tabular}

Tabel 2 nilai interval item rating scale

Bila instrumentersebut digunakan sebagai angket yang diberikan pada 15 responden, maka sebelum dianalisis data dapat ditabulasikan. Jumblah skor kriterium( bila setiap butir mendapat skor tertinggi $5 \times 7 \times 17=525$. Untuk ini skor tertinggi 4. Jumblah butir $=7$ dan jumblah responden $=15$. Jublah daa skor hasil pengumpulan data adalah 349 dengan demikian, kualitas video conerence menurut persepsi 15 responden yaitu 349:252=66\% dari criteria yang ditetapkan. Hal ini secara kontinyu dapat dibuat kategori sebagai berikut.

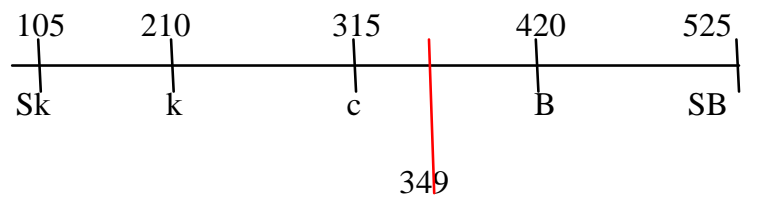

349 Termaksud dalam kategori interval" cukup baikdan baik. Tetapi lebih endekati cukup baik.

\section{DISCUSSION}

Kesimpulan. Setelah penulis melakkan analisis terhadap system Video Conference Polycom VSX 7000 pada Universitas Bandar Lampung, makapenulis mengambl keimpulan bahwa:

1. Video Conference Polycom VSX 7000 telah memenuhi standar ITU (International Teecommunication Union)

2. Berdasarkan penilaian hasil kuisioner yang ditujukan pada responden, memperoleh nilai9 termaksud dalam kategori interval " cukup baik:" dan "baik". Artinya kualitas Video Coference yang ada masih perlu diperbaiki atau maintenance.

3. System kerja perangkat Video Conference Universitas Bandar Lampung saat terhubung dengan MCU INHERENT DIKTI mengguaka Sistem Video Streaming.

4. Bandwidth yang disediakan dengan yang dibutuhkan kurang sesuai, sehingga mengakibatkan tampilan gambar dan frekuensi suara kurang baik. Karena semakin rendah kapasitas bandwidthnya, maka semakin rendah juga daya kecepatan transfer data dan suara, serta buruknya kualitas video dan gambar yang sedang dikirim.

Saran. Beberapa saran yang dapat diberikan untuk pengembangan lebih lanjut,yaitu:

1. Disediakanya bandwidth yang lebih besar untuk menghasilkan focus suara dan gambar yang jelas.

2. Semakin peatnya pertumbuhan telekominikasi. Memungkinkanpeangkat telekomunikasi menjadi using. Sehingga perangkat Video Conference yang di Universitas Bandar lampung seharsnya diperbaharui.

3. Peangkat endpoin yang muah panan menimbulkan ganguan koneksi. Sehingga harus beroperasi normal pada suhu $0-40^{\circ} \mathrm{C}$.

\section{REFERENCES}

JOGIANTO,h.m. Analisa dan Design. Yogyakarta,Ani Offset, 2005.

Sugiono, Metode Penelitian Pendidikan Pendekatan

Kuantitatif, dan R\& D,Alfabeta, Bandung, 2009

Sutabi,Tata.SM,Yogyakarta,Andi Offet, 2005

Dharwiyanti,Sri. Pegantar Unified Modeling Language. Badung, Jakarta,Andi Offset,2003

http://dslrouter.sourceforge.net/stuff/jadiknas/jardiknas\%2 Opustekom/Modul_10_Vicon.pdf

http: // www.inherent-dikti.net/

http://romisatriawahono.net 